\title{
CORPUS Corpus
}

Archivos virtuales de la alteridad americana

Vol 6, No 2 | 2016

Julio / Diciembre 2016

\section{In defense of ecuaros and biodiversity in a Purhépecha community, Michoacán, Mexico}

En defensa de los ecuaros y la biodiversidad en la comunidad de Purhépecha, Michoacán, Méjico

Wendy M. Harvey

\section{OpenEdition}

\section{Journals}

Electronic version

URL: http://journals.openedition.org/corpusarchivos/1660

DOI: 10.4000/corpusarchivos. 1660

ISSN: $1853-8037$

\section{Publisher}

Diego Escolar

\section{Electronic reference}

Wendy M. Harvey, «In defense of ecuaros and biodiversity in a Purhépecha community, Michoacán Mexico », Corpus [En línea], Vol 6, No 2 | 2016, Publicado el 22 diciembre 2016, consultado el 02 mayo 2019. URL : http://journals.openedition.org/corpusarchivos/1660 ; DOI : 10.4000/ corpusarchivos. 1660

This text was automatically generated on 2 May 2019. 


\section{In defense of ecuaros and biodiversity in a Purhépecha community, Michoacán, Mexico}

En defensa de los ecuaros y la biodiversidad en la comunidad de Purhépecha, Michoacán, Méjico

Wendy M. Harvey

\section{Introduction}

1 This paper focuses on the importance of ecuaros (home gardens) in San Lorenzo, a Purhépecha community in the western state of Michoacán, Mexico. Despite the loss of tradition in conserving ecuaros, this paper argues that they represent a potential economic benefit for community members, as well as contributing to the preservation of biodiversity. The role of ecuaros has been understudied but offers important lessons in the conservation of culturally significant plants and food varieties.

This paper also adds to the literature on home gardens in Latin America. Several authors have noted how home gardens are an important source of edible, medicinal and ornamental plants that rely on local knowledge and practices of women (Galhena et al. 2013; Gasco 2008; Lok 2001; Murrieta \&Winkler-Prins 2003; Singh et al. 2013). For example, in the lower Amazon region, Murrieta \& Winkler-Prins found that women are the principal managers of home gardens, while men tend to work outside. As a result, women continually renegotiate gender relations and their social status. The exchange of fruits and plants also supports affective social ties among neighbors and women in the community. Another important aspect of home gardens is the diversity of management strategies that are used by women, in some cases allowing for wild plants to grow freely, while in others, favoring a more closely controlled home garden. The potential benefits of home gardens have been noted by Gasco (2008), who argues that "these systems can serve as models for the design of tropical forest management strategies that will both slow the 
pact of deforestation and meet the health, social and economic needs of populations in the tropics." (p. 273). If these benefits are to be achieved, it is also necessary to take into account the pressures and threats facing biodiversity conservation. For example, in their study of home gardens in two rural communities in Costa Rica, Zaldívar et al. (2002) noted how colonization has led to a depletion of biodiversity. As I argue in this paper, it is important to take into account such pressures and their impact on women's ability to sustain traditions of home garden management.

3 The paper is organized in six sections. The first section provides the rationale for this study by conceptualizing ecuaros as an alternative system of local food production that counters the dominant, neoliberal model of commercial agriculture. I then describe my methodology and choice of location and research participants. The third section presents a summary of the historical evolution of ecuaros in Michoacán and draws on my ethnographic research to examine their role in food production and community traditions, as well as noting their current decline. The fourth section discusses diverse uses of ecuaros in San Lorenzo and compares the ecuaros of two sisters, Beatriz Alicia and Mónica, with regard to the various aesthetic, economic and seasonal aspects of ecuaro production. The fifth section considers ecuaros as social spaces through which knowledge is passed on from mothers to daughters and notes how the exchange of ecuaro products as gifts helps to strengthen family and community ties. The final section discusses relationships between ecuaros and outside markets, particularly the impacts of such relationships on women's incomes and the decline of ecuaros. The paper concludes by reflecting on the challenges facing ecuaros and the need for new policies to recognize and support this important alternative in the face of declining food sovereignty.

\section{Ecuaros and the neoliberal restructuring of agriculture}

4 In this paper I argue that ecuaros can be understood as an important part of local food systems that have been undermined by economic globalization, but which also represent an alternative means for increasing food self-sufficiency in culturally appropriate and ecologically sustainable ways.

The viability of ecuaros is, like that of many aspects of rural Mexico, shaped by the capitalist transformation of agriculture and global trade. During the 1980s the International Monetary Fund (IMF) and the World Bank (WB) placed conditions on new loans and rural development programs that obliged countries in the global South to adopt structural adjustment policies such as trade liberalization, the reduction or elimination of subsidies to small farmers and the privatization of public enterprises. These policies formed part of what became known as the "Washington Consensus," a convergence of policy prescriptions which sought to promote global trade through new accords such as the North American Free Trade Agreement (NAFTA) between the US, Canada and Mexico, which came in to effect on January 1, 1994. The ideology of neoliberalism came to describe such policies as they sought to renew the economic liberalism of the nineteenth century by reducing government intervention in the capitalist market and facilitating private enterprise. The creation of international rules to reflect the neoliberal character of globalization was most clearly expressed in the establishment of the World Trade Organization (WTO) in 1995. Significantly, adoption of the WTO's "Agreement on 
Agriculture" prohibited the use of public policies such as guaranteed prices and restrictions on imports as means to support domestic producers, although in practice such rules have been followed less by wealthier countries of the global North than the poorer countries of the global South (McMichael 2012, p. 59).

Neoliberal policies have helped create a global market in which import tariffs have been reduced or eliminated by many countries, which has led to increased imports of grain from exporting countries and the displacement of small producers. By the end of the twentieth century, an estimated 20 to 30 million people had lost their land due to the effects of trade liberalization and the promotion of crops for export (McMichael 2010, pp. 60-61). In the case of Mexico, the rapid increase in corn imports from the US after 1994 led to millions of peasants leaving their land as they migrated to the US or to poor urban peripheries in Mexico (Bellow \& Baviera 2010, p. 40). At the same time, the Mexican government cut subsidies to small farmers, arguing that Mexico had to focus on its supposed comparative advantages in the global economy. As a result, the agribusiness firms that produce seasonal fruits and vegetables for export have been the most favored by neoliberal policies. They profit further from the exploitation of the labor of displaced peasants.

7 One of the most worrying consequences of this situation is the increase in hunger, despite the fact that there is enough food being produced to meet the nutritional needs of the world's entire population. By 2010, an estimated one billion people (one sixth of humanity) suffered from severe hunger, while as many as another two billion people lived in perpetual food insecurity (Magdoff \& Tokar 2010, p. 12).

8 This level of hunger can be explained by noting long-term trends such as the growth of the meat industry which has displaced grain production away from human to animal consumption. Similarly, the promotion of neoliberal policies such as trade liberalization has led to a process of depeasantization as local producers are unable to compete with the influx of cheaper grains. As a result, the production of grain has declined in poorer countries, while the simultaneous concentration of corporate ownership has allowed a handful of transnational firms, such as Monsanto, to exercise a monopoly at each stage of an integrated global food system.

9 The loss of food security for large sectors of the population was also deepened after 2007 due to extreme drought in grain producing areas, the displacement of grains for the production of biofuels and financial speculation in food as a commodity. The spike in food prices in 2008 forced many of the world's poor to cut back consumption or switch to cheaper but less nutritious foods. The crisis also sparked food riots in several countries, including Mexico (Bello \& Baviera 2010, p. 39). In post-NAFTA Mexico the government has marginalized small producers while privileging hi-tech, export-oriented agribusiness firms. An additional consequence is the lack of research and technical assistance necessary for supporting the in situ conservation of maize varieties that has traditionally been carried out by small farmers (Keleman 2010).

10 It is in this context that we need to understand the importance of local food systems, such as ecuaros, and how broader economic changes have undermined their ability to contribute to self-sufficiency and biodiversity conservation. Neoliberal policies have instead encouraged urbanization and the penetration of imported processed foods into local markets, leading to changes in people's diets (Magdoff \& Tokar 2010, p. 22). Unable to compete with cheaper imported grain, many small producers have been forced to migrate to the US in order to earn enough to support their families. In Michoacán we 
have also seen the expansion of drug cartels across large parts of the state as local traffickers have taken advantage of the withdrawal or reduction of government agencies and programs as part of neoliberal structural adjustment (Maldonado Aranda 2012). Each of these factors place great pressure on small farmers and indigenous communities, including the ability to sustain practices such as the use of ecuaros.

\section{Methodology}

This study formed part of my Master's thesis in Anthropology, completed in 2008 at New Mexico State University. The findings are based on ethnographic field work which I conducted in San Lorenzo, Michoacán. I visited the community on four occasions. The first was in November 2006 when I made my initial contact and stayed in the community for one week. I then spent ten weeks living with a Purhépecha extended family in the community during the summer of 2007 and returned on two further occasions, in July 2008 and July 2012, for one week each.

12 I chose this community because I wanted to study women's participation in the conservation of biodiversity and in the reproduction of cultural practices related to cooking. I wanted to give more attention to women's work and ecuaros because most of the literature on Mexican peasant economies tends to focus on men's work outside the home. I presented my proposed research to a group of eight women during my first visit and obtained their consent to participate in the study. I used participant observation and interviews of women regarding their use of ecuaros in cooking traditional dishes and exchanging food with other community members.

13 I also chose this community because it was relatively accessible by public transport. Due to the problems of violence and insecurity in the region, I have not been able to return since July 2012 although I still keep in contact with some of the women.

\section{History and literature regarding ecuaros}

\subsection{History of Ecuaros}

The ekuarhu, or ecuaro, is a subsistence system that contributes to the self-sufficiency of Purhépecha families. There is little information about them due to the destruction by the Spanish conquerors during the colonization. There is only one main source, called the Relación de Michoacán (Alcalá 2010). It was during these times that the indigenous communities were formed around the missions, and the tradition of gardening was seen as a good activity by the missionaries (Dunmire 2004, p. 125). Bibliographical searches only produced articles about home gardens in other regions, but not about the community of San Lorenzo. There is a larger literature about pre-Hispanic agricultural systems in Mexico, but most studies tend to focus on the central valley where the Spanish conquerors first encountered the advanced organization of food production under the Aztecs.

By the time of the Spanish conquest in the early sixteenth century, central Mexico was a very important area of food production with over one hundred species domesticated for food, fiber and medicinal uses (Dunmire 2004, p. 34). The soil was fertile and deep, and the Valley of Mexico was made up of a chain of shallow lakes and marshes. The Aztecs 
made use of these conditions in a very productive way by developing a system of "swamp gardening" (or, chinampa agriculture). They drew up dirt from the lake beds to make mounds along the shores that were held together by willow branches and trees. These wetland fields were highly productive, and it is estimated that by the early 1500 s between 40,000 and 50,000 square meters of chinampas were under cultivation, producing enough to feed up to 270,000 workers. As Dunmire notes: "These were the most intensively cultivated lands in prehistoric America, and few, if any, farming systems in the world could match Aztec levels of productivity" (2004, p. 35).

Although chinampa agriculture was unique because of the abundance of water and marshes, other regions of Mexico, such as present-day Michoacán, were also very fertile and allowed for subsistence production for the population prior to the conquest. The conquerors produced important changes as the native population was decimated by violence and disease, as well as by the policy of forced concentration in new settlements that would serve the labor needs of the new rulers. One result of this was that indigenous people lost land but were able to farm small plots in order to survive. For the Spaniards, subsistence plots were seen as a way of lowering the cost of feeding the native population, but the Spaniards also allowed the native population to continue using their knowledge of local plant varieties as they tried to survive the effects of the conquest. Ecuaros thus represented a combination of pre-Hispanic agricultural systems of production and a new agricultural system imposed by colonial rule. In this way, they resemble the strategies used by African slaves in the Caribbean, as described by Mintz (1996). In addition, since the continuation of ecuaro agriculture was carried out by women, it was largely ignored by outside observers as a significant activity. Over time, women incorporated European foods, such a peaches and other fruits, into their ecuaros, leading to the gradual hybridization of Purhépecha cuisine that we know today.

Despite the lack of outside attention, home gardens have been very important in providing a means of subsistence and a source of food for women to manage in order to feed their families. For many years, ecuaros in the Meseta Purhépecha have benefited from the fact that they are located in an area of abundant water and fertile land (The Nature Conservancy 2007). However these conditions have changed in the past two decades, due to a rapid process of deforestation and subsequent loss of water availability.

Although official programs of reforestation have been implemented, some local people argue that these programs have not been successful and have even been harmful in that they have taken land away from ecuaros for sake of planting trees (comment of daughter in law of Doña Claudia Valles). At the same time, there have been efforts to conserve biodiversity in protected areas. For example, if we take the road out of San Lorenzo towards Uruapan and travel a short distance, there is quite a large garden where we can find a significant part of the region's biodiversity.

\subsection{Role that ecuaros have played in food production and the community}

These sources of food production in the community have not been highly valued, even though the ecuaro has served mainly to meet the needs of the extended family. The ecuaros have been important because for many years, when there were no paved roads connecting the rural communities to the urban centers, they provided women with ingredients for cooking the different types of dishes to feed their families. Despite the 
isolation, Purhépecha women were able to provide a wide range of fruits and vegetables for their families. In essence, the ecuaro played a critical role in supporting food selfsufficiency and subsidizing food production within rural Michoacán.

The community of San Lorenzo, where I carried out my study, is located in the Meseta Purhépecha region. Besides providing food for the community, the ecuaros also allow women to establish strong social relationships of mutual aid and reciprocal exchange of ingredients between different ecuaros. These relationships are maintained by women in the community and the exchange of food reinforces the social bonds within the community. In addition, women pass down ecuaro knowledge orally from generation to generation, vertically from mothers to daughters, and horizontally among members of the community. This knowledge is bound up with the preparation and consumption of the different dishes that people eat in their everyday meals or at parties. At the same time, women use their knowledge to maintain biodiversity because, by growing and tending to different plants, they help adapt them to the environment. This occurs with corn, beans, chile, squash and some quelites.

The work that women do in their ecuaros contrasts with the work carried out by men in their milpas. Among the Purhépecha, there is not a rigid distinction between the milpa and the ecuaro, since women also help in maintaining the milpa. I did not see any men helping women in the ecuaros nor in the kitchen. Women contribute to work in the milpa by selecting which corn seeds should be sown. For example, Don Mario, the husband of Doña Elia, farms his milpa, a task that women themselves consider to be men's work. He mainly grows corn, although this is sown in rows that are inserted between other rows of squash and beans to provide more oxygen to the milpa. It should be noted that this multicropping demonstrates continuity with pre-Hispanic agriculture. The Spanish model of farming was based on a monoculture and extensive ranching production, which was itself imposed by the Moors and had previously destroyed Spain's own diversity of food production (Dunmire 2004, p. 114), so the fact that Don Mario and other Purhépechas continue to mix crop production is a sign of continuity of indigenous practices.

On some Fridays women in Doña Elia's family go with their children to Don Mario's milpa to help him weed his plants and apply fertilizer since he is disabled in half of his body (observation). Despite his disability, the community considers Don Mario to be a hardworking man, and the women go to help and see if his corn is growing well. Women are the ones who also select the corn that will be sown for the next harvest.

With regards to the ecuaros, women told me they do not use fertilizers to look after them. Most of the eight women that I interviewed reported that they only use encino (live oak) soil as a fertilizer, and said that they just sweep them and clean them every three days, or in some cases, every day, in order to keep the ecuaro clean. In the ecuaros, women hang out the corn cobs to dry. When the cobs are ready, the women remove the seeds and give the best ones to the men to sow in the milpa alongside the squash and beans to provide nutrients to the soil.

24 If we compare the milpa with the ecuaro, we find many differences. The first one is that the milpa is located far from the home and thus is considered part of the outside world. The milpa comprises men's work, although women contribute some of the labor, while the ecuaro is situated close to the home. Women grow the plants and herbs that they use in daily cooking, and the ecuaro is considered a woman's space, a space that is almost part of the inside of the home. Another difference is that in the milpa, corn, beans and squash 
are traditionally grown, while the ecuaro is a more diversified system. Men use the milpa to produce crops that will be sold for cash although part of the production is for domestic consumption. The ecuaro, in contrast, is smaller than the milpa and is used mostly for domestic consumption. Women use the ecuaro as a source of self-sufficiency to feed their families although some women also sell part of their production. Women use the products of their ecuaros in cooking and in decorating their homes. While milpas are dedicated mainly to one crop (corn), ecuaros have several food varieties, as well as ornamental flowers, fruit trees and medicinal plants. There is greater crop diversity in the ecuaros than in the milpas, and this diversity helps maintain a balance that prevents the incidence of pests in the area where plants are grown (Mapes $\mathrm{s} / \mathrm{f}$ ).

\subsection{Limited research on ecuaros}

For a long time, the study of ecuaros has been neglected. On the one hand, researchers have focused more on commercial agricultural production, and when scholars have recognized the importance of subsistence production, they have focused on the milpa, not the ecuaro (Barkin 1985). Although indigenous people have maintained a constant source of food in their ecuaros since the sixteenth century, scholars have been blind to the vital role of this form of production. As a result, researchers have also given most attention to the work performed by men, and have failed to take into account women's contributions. For some scholars women's work plays a complementary role (Rodriguez Lazcano 1993) and they themselves, as women, were not even aware of being subordinated. On the other hand, anthropological studies have been dominated by men whose training in the discipline and their position as men did not prepare them to work closely with women. These two factors may explain the relative neglect of women's participation in society, as well as the little attention given to the ecuaros. Today it would be negligent not to see this (Christie 2002).

\subsection{Current Decline of Ecuaros}

A big problem is that the community of San Lorenzo lacks water and sewage systems. As a consequence, water is used for the most immediate needs such as bathing and washing clothes. Another latent problem is the excessive cutting of trees which is producing scarcity of water due to the reduced capacity of the soil to retain the water. In addition, there are now paved roads that provide easy transportation and movement between the communities and the larger towns and cities. In the case of San Lorenzo, this communication has existed since the late 1970s. This has led to a decline in the contribution of ecuaros to self-sufficiency since closeness to the towns has made it easier to obtain products that are used as ingredients in regional dishes without having to work in the ecuaros to produce the same products. As a result, women show less interest in growing ingredients for subsistence needs.

There are two large markets to which the people of San Lorenzo have access. One is the market of Uruapan, which is approximately fifteen kilometers away. The other is the market of Paracho (located at about the same distance). People tend to prefer the Paracho market as it is more indigenous while being more accessible, due to the fact that there is a lot more traffic on the road to Uruapan. The community also has its own mobile market which is quite small but meets the immediate needs of its clients at higher prices. For this 
reason, women prefer to shop in the markets and buy what they need for the week at lower prices. There are also small grocery corner stores when people can buy ingredients that they forgot to buy at the market and which they need to make their meals. These corner stores also sell canned foods and children's snacks. It is this access to markets and stores that has led to a decline in interest in ecuaros and, as a result, the loss of such an important means of food production and subsistence.

Another internal factor that explains the decline of ecuaros is the growth of population in a limited area, following a patrilocal post-marital residence pattern. For example, if women have male children, mothers have the custom of providing accommodation to their married sons and families in part of the area occupied by their own homes. This means that the area that was previously dedicated to being an ecuaro is now being used instead to help accommodate more people and ecuaros are being turned into patios or gardens. As a result, we see the loss of plots and land dedicated to food production as this space is increasingly used by more family members. For example, whereas twenty years ago a nuclear family lived in a particular home, now we find an extended family in the same area.

Another cause is the deficient educational system. Due to the lack of adequate schooling, most young men decide to stay in the village in order to make a living from the cutting of trees in the nearby forests. The educational system is not in step with the community's customs and those who do not stay to cut timber become migrants. For example, in San Lorenzo it is seen as a great thing when children finish their primary school and the community holds a big celebration for this day in the year. However, the people also know that the content of the educational curriculum is not useful since it does not reflect their own needs as Purhépechas. One of the women I interviewed, Coquis, the daughterin-law of Doña Elia, mentioned that while some political groups were promoting the opening of another school (and thereby creating divisions within the community), she and other women felt that it was unnecessary to fight over this issue because what is important is not to have more schools, but rather to get married and serve the community. Increased migration, both male and female, to obtain more income also causes less interest in maintaining ecuaros and a tradition which for many years provided sustenance is being lost. Migration creates a gap in the community between modern customs that migrants adopt, and traditional ways of the community.

\section{Ecuaros in San Lorenzo: the cases of Beatriz Alicia and Mónica}

30 As noted above, there is little scholarly research on ecuaros. The concept of ecuaro has changed to the point that now, for most women, what is considered an ecuaro is in reality a small area of a garden within the home. The home is no longer the traditional timber home, or troje, but has been replaced by cement structures which are considered to be more durable. The area that previously belonged to the ecuaro has been absorbed into the home, but women still grow some plants that they use in preparing dishes. Some still have a fruit tree, but mainly they still use this area for growing ornamental flowers with which to decorate their homes. 


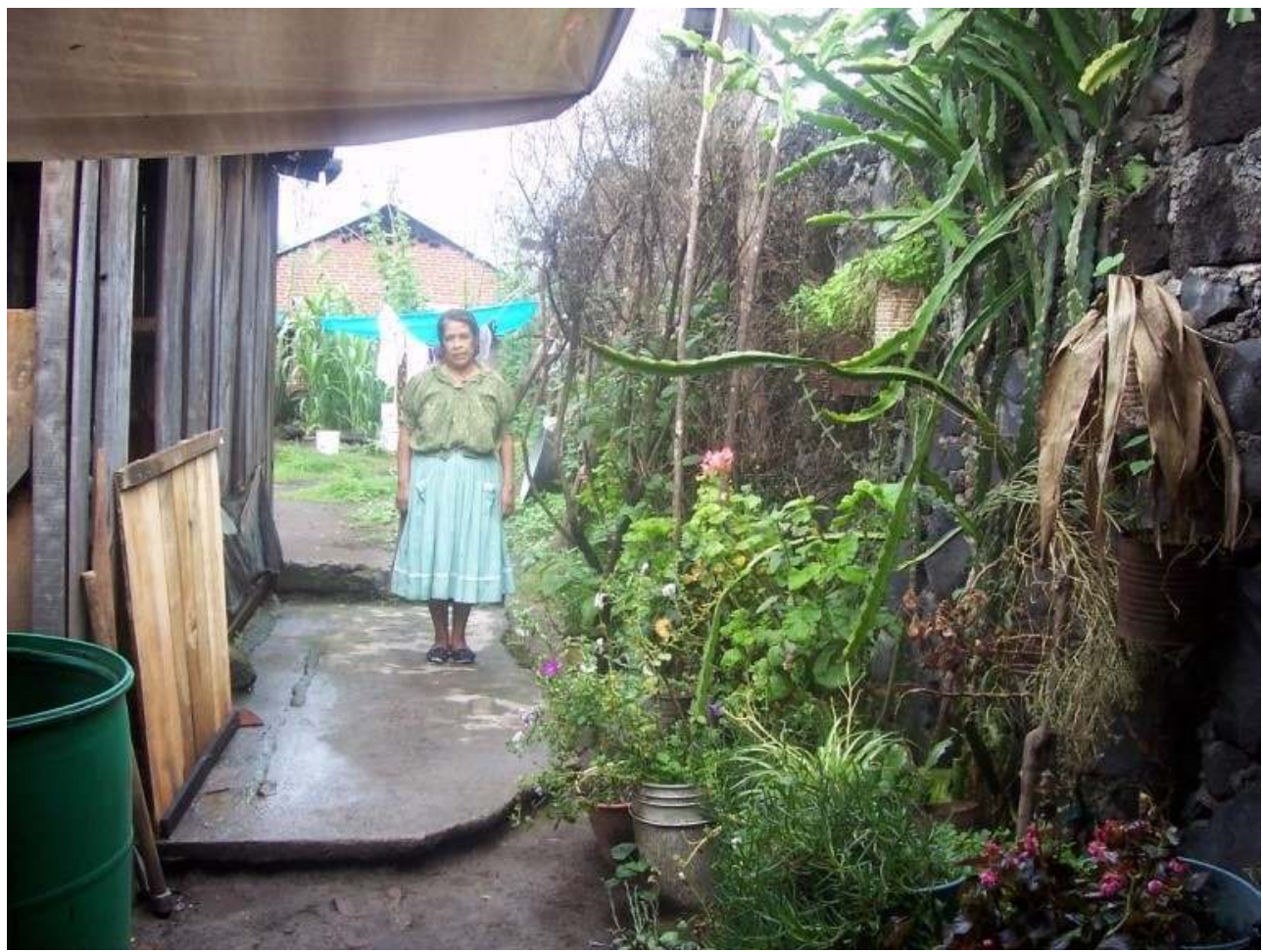

Figure 1: Doña María Concepción with the little that is left of her ecuaro (Source: author)

Some of the women whom I interviewed had hardly any space left for growing plants and one of them (Doña Claudia Valles) had her entire patio paved. Another woman, Doña María Concepción, had all her plants in tins or chile cans arranged on a wall because she had given the area that had been her ecuaro to her son and daughter-in-law to build their own home. For this reason, the limited space is used for growing ornamental plants and flowers, for Purhépecha women do not feel happy without some flowers to decorate their homes. Of the eight women interviewed, only two (Beatriz Alicia and her sister Mónica) had ecuaros that really occupied a considerable area with regard to the amount of plants being grown and used by themselves, in comparison with the gardens of the other six women. The following tables show the variety of plants in the ecuaros of Beatriz Alicia and Mónica.

Table 1: Biodiversity of Beatriz Alicia's Ecuaro

\begin{tabular}{|c|c|c|c|c|c|}
\hline $\begin{array}{l}\text { FOOD } \\
\text { PLANTS }\end{array}$ & MEDICINAL PLANTS & $\begin{array}{l}\text { FRUIT } \\
\text { TREES }\end{array}$ & $\begin{array}{l}\text { NON- } \\
\text { FRUIT } \\
\text { TREES }\end{array}$ & SHRUBS & $\begin{array}{l}\text { ORNAMENTAL } \\
\text { FLOWERS }\end{array}$ \\
\hline \multirow{2}{*}{ Nopal pan } & \multirow{2}{*}{ Medicinal rose } & \multirow{2}{*}{ Apple } & \multirow{2}{*}{ Cedar } & Tejocote & \multirow{2}{*}{$\begin{array}{l}\text { Copihue (colibris } \\
\text { like this) }\end{array}$} \\
\hline & & & & (hawthorn) & \\
\hline Agave & Rue (ruda) & Avocado & $\begin{array}{l}\text { Weeping } \\
\text { willow }\end{array}$ & $\begin{array}{ll}\text { Wild } & \text { white } \\
\text { bramble } & \end{array}$ & Orange blossom \\
\hline
\end{tabular}




\begin{tabular}{|c|c|c|c|c|c|}
\hline Sugar cane & Vapor rub & $\begin{array}{l}\text { banana } \\
\text { plátano de } \\
\text { semilla })\end{array}$ & Willow & $\begin{array}{l}\text { Queen } \\
\text { bush }\end{array}$ & Honeysuckle \\
\hline $\begin{array}{l}\text { Purhépecha } \\
\text { bean (two } \\
\text { varieties) }\end{array}$ & Mint & $\begin{array}{l}\text { macadamia } \\
\text { nut }\end{array}$ & Pine & Creole rose & Orchids \\
\hline Corn & White toronjil & Orange & Ash & White paloma & White toronjil \\
\hline Chile perón & $\begin{array}{l}\text { Flor de Tilo (also } \\
\text { used for wrapping } \\
\text { corundas) }\end{array}$ & Mandarin & $\begin{array}{l}\text { Wild } \\
\text { willow }\end{array}$ & sagebrush & Verónica \\
\hline Saffron & & White plum & & White jeringuilla & Rose \\
\hline $\begin{array}{l}\text { White and } \\
\text { brown } \\
\text { nopalillo }\end{array}$ & & Red plum & & Wild rose & Lily \\
\hline Parsley & & Peach & & Patas de buey & $\begin{array}{l}\text { Red mallow } \\
\text { flower }\end{array}$ \\
\hline Pepper & & White fig & & & Chrysanthemum \\
\hline \multirow[t]{12}{*}{ Chayote } & & Medlar & & & Obelisque \\
\hline & & Capulín & & & Alcatraz \\
\hline & & Guanábana & & & White mallow \\
\hline & & Grapefruit & & & Paloma \\
\hline & & Lime & & & Aromatic glorias \\
\hline & & Banana & & & Flor Xavikua \\
\hline & & $\begin{array}{l}\text { Red } \\
\text { grenadine }\end{array}$ & & & Carmine rose \\
\hline & & & & & Pascua \\
\hline & & & & & Gladiola \\
\hline & & & & & Dahlias \\
\hline & & & & & White lily \\
\hline & & & & & Pansies \\
\hline
\end{tabular}

Source: author's field notes 
Table 2: Biodiversity of Mónica's Ecuaro

\begin{tabular}{|c|c|c|c|c|c|}
\hline FOOD PLANTS & $\begin{array}{l}\text { MEDICINAL } \\
\text { PLANTS }\end{array}$ & $\begin{array}{l}\text { FRUIT } \\
\text { TREES }\end{array}$ & $\begin{array}{l}\text { NON- } \\
\text { FRUIT } \\
\text { TREES }\end{array}$ & SHRUBS & $\begin{array}{l}\text { ORNAMENTAL } \\
\text { FLOWERS }\end{array}$ \\
\hline $\begin{array}{l}\text { Pumpkin flowers } \\
\text { (flor de calabaza) }\end{array}$ & Estafiate & Apple & $\begin{array}{l}\text { Pine (Pino } \\
\text { de ceniza) }\end{array}$ & & $\begin{array}{l}\text { Alcatraces (red, yellow, } \\
\text { pink, cream and white) }\end{array}$ \\
\hline Nopales & Crespón & Pear & $\begin{array}{l}\text { Small } \\
\text { pine } \\
\text { pinito })\end{array}$ & & $\begin{array}{l}\text { Azaleas, bugambilia } \\
\text { color with white stripes }\end{array}$ \\
\hline Chile perón & Espiguilla & Lemon & & & Palomas \\
\hline Cilantro & Vick vapor rub & Orange & & & $\begin{array}{l}\text { Carmelinas (bugambilia } \\
\text { colored) }\end{array}$ \\
\hline Carrots & White toronjil & Peach & & & $\begin{array}{l}\text { Belenes } \quad \text { (orange } \\
\text { colored) }\end{array}$ \\
\hline $\begin{array}{l}\text { Greens (hortalizas } \\
\text { ) }\end{array}$ & & Grenadine & & & $\begin{array}{l}\text { Belenes (dark pink with } \\
\text { white stripes) }\end{array}$ \\
\hline \multirow[t]{7}{*}{ Radishes } & & Nísperos & & & $\begin{array}{l}\text { Azucenas (different } \\
\text { colors) }\end{array}$ \\
\hline & & $\begin{array}{l}\text { Criollo } \\
\text { Avocado }\end{array}$ & & & Yellow Lilly \\
\hline & & Chilacoyote & & & Mallow \\
\hline & & Chayote & & & $\begin{array}{l}\text { Geranium, bugambilia } \\
\text { color }\end{array}$ \\
\hline & & Capulin & & & Mountain orchids \\
\hline & & & & & Spring orchids \\
\hline & & & & & Dahlias \\
\hline
\end{tabular}

Source: author's field notes

\subsection{Organization of ecuaros}

With regard to the organization of ecuaros, each woman provides her own personal touch, just as noted later in the way that kitchen space is organized. As mentioned above, ecuaros have been converted into gardens that are mainly used for growing ornamental plants, although some still have food plants and fruit trees, with only two women maintaining ecuaros as systems of food production. The latter two women are sisters and, from ecuaro 
to ecuaro, we can observe big differences. The arrangement in each ecuaro is based on their personal needs. While Beatriz Alicia has a wide variety of plants in her ecuaro, the internal order reflects her particular needs and personality. This was most evident in the case of Beatriz Alicia. She lives alone and is one of the few women in the community who knows how to read and write. Above all, Beatriz Alicia cultivates the arts. She writes poetry and sews. She is a woman who refused to get married and preferred instead to leave the community to get a formal education (although she was unable to achieve this). By leaving the community, she was criticized by men and women alike and she felt very lonely. Her situation is therefore different to that of the other women. This is the order that she has imposed in her ecuaro. For example, the ecuaro of her sister, Mónica, has an order that responds to her external needs and is more structured with regard to arrangement and separation of plants according to their uses. When you enter Mónica's ecuaro you see on the left the medicinal plants. In contrast, when you enter Beatriz Alicia's ecuaro you see on the left plants that are arranged in order to serve and decorate her house. She mixes parsley with pine, peppermint with malvas, etc. This does not mean that Mónica does not appreciate the aesthetic importance of her ecuaro because she grows the plants and flowers that she likes, and is proud of how she looks after it, as she told me in her interview:

I clean (my ecuaro) every day; I get up at five o'clock in the morning to clean it all because it is a lot of work. Here you need a special kind of gardener, don't you think? But, in order to save my money, I do it all by myself. I do everything alone, sometimes at night, sometimes in the early part of the morning, and that is how I spend my time, you see, always doing something, tidying up my garden, because I love my garden, I live, I like to live amid the greenery, my house is almost like a jungle, I think people even laugh about me because of I have so many plants (she laughs).

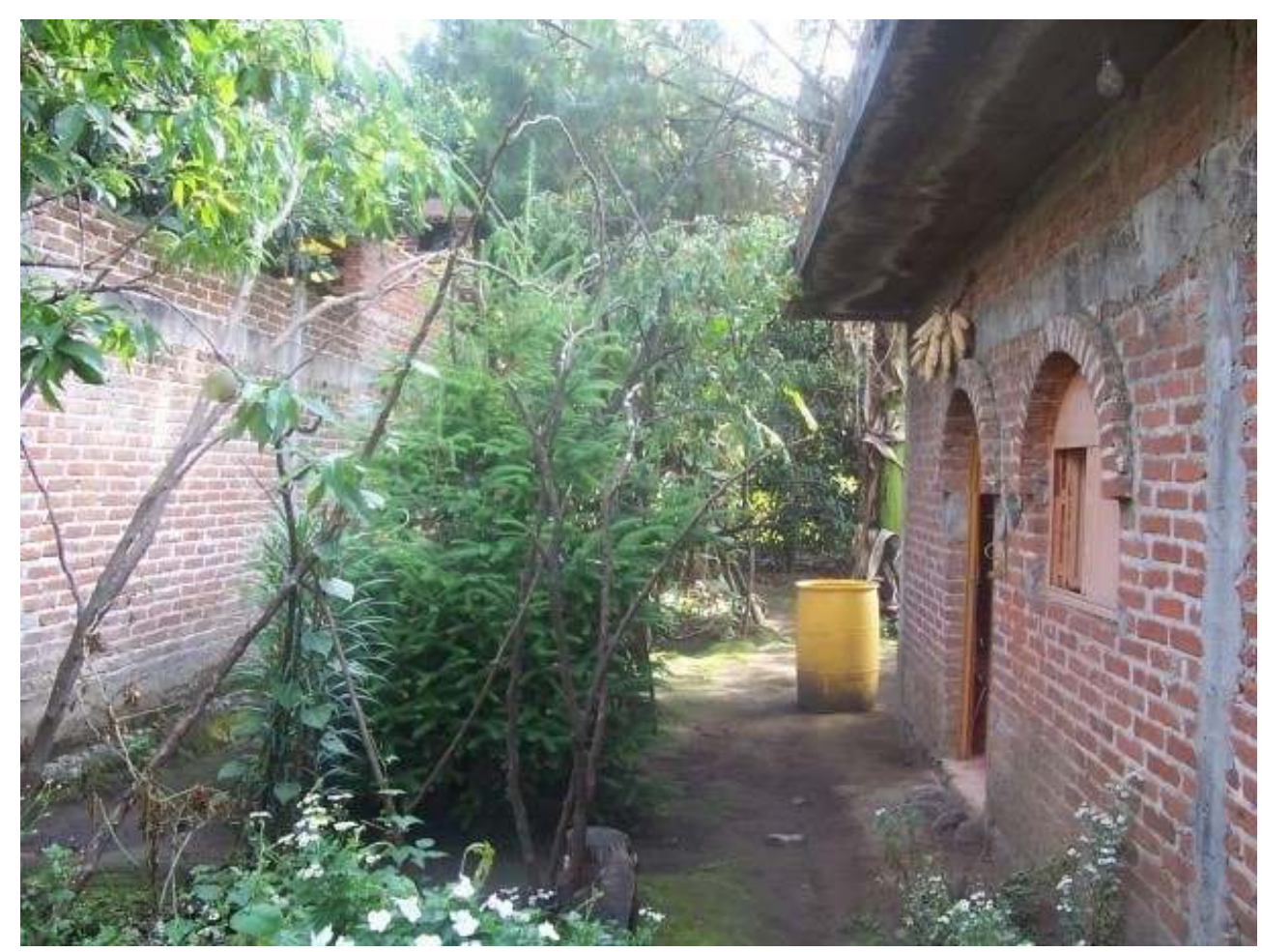

Figure 2: Ecuaro of Beatriz Alicia (Source: author) 


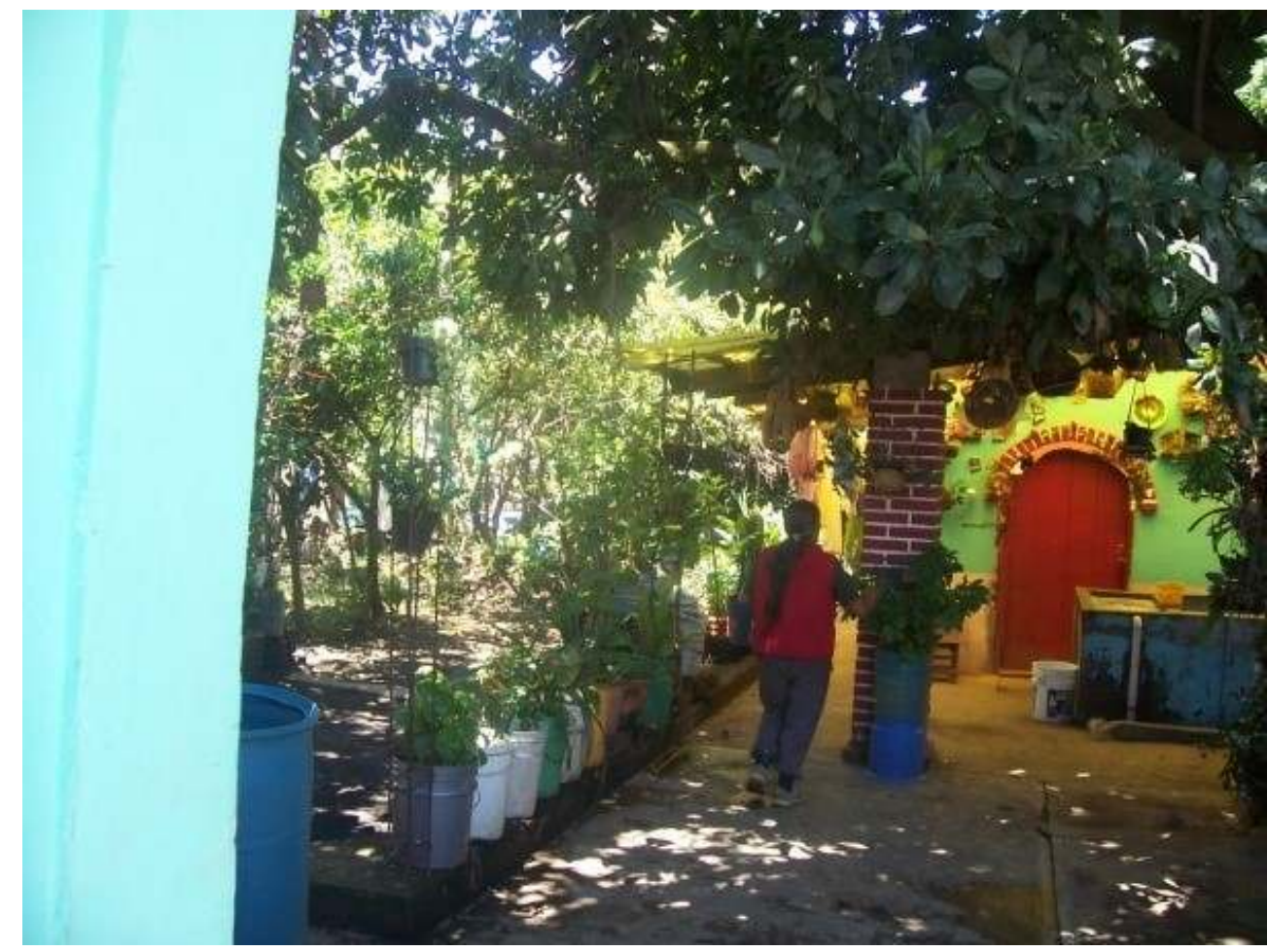

Figure 3: Ecuaro of Mónica (Source: author)

Beatriz Alicia's way of organizing her ecuaro is not based on the idea of dividing plants according to their medicinal or ornamental use, or of separating them out by the type of fruit produced. Beatriz Alicia simply places them in her ecuaro, because for her these plants are beautiful, "they are a work of art," as she said in one of our interviews, when responding to my question of how she created her ecuaro:

[I made my ecuaro] with a lot sacrifice because sometimes you are covered in dirt and poor, but I do all this with a lot of joy, with a lot of love; this began in my childhood, because the roads littered with trash, there on the roads, that began in the 1970s, then they started to build the roads; (but) I grew up surrounded by beautiful woods, like I was living in a forested paradise. My father had pine forests and he planted a lot of wheat, beans and corn, and in later years he planted corn and beans. I grew up with all of that and I always dreamed about having plants and trees. Whether married or not, that was my main goal, that wherever I lived I would have trees and plants, and, thanks to sacrificing so much work, I put a lot of time into it, so you see, I want to make a work of art; I recall how I dreamed about my childhood, and now that I am older I can see that, thanks to putting my effort into this work, part of my consciousness has been opened up. So, one day, I want to publish a bilingual account in Purhépecha and Spanish of the "vision of life," that speaks about wild flowers and plants with Purhépecha names. This one is called saluantsutusqui, and it was from this that the dahlia was born. Saluan is the original, and so I made a composition. I want to express this, I want to create a work of art, it is the plants, that is, this made me dream of my childhood; this opened up part of my consciousness.

Beatriz Alicia does not think about selling the products grown in her ecuaro and, although she has fruit trees and edible plants, her way of organizing her ecuaro is based on aesthetic satisfaction rather than the more pragmatic model adopted by her sister, Mónica. Another difference that shows a contrast between internal and external purposes 
of ecuaros is that Beatriz Alicia maintains diversity by just having one of each type of plant, while Mónica produces several of the same plant in a small area so that she can sell them in the market. Beatriz Alicia thinks of her garden more as a work of art, as her own creative expression. She even sees musicality in the Purhépecha names of the different plants, whereas Mónica no longer has a good knowledge of the Purhépecha names of the plants in her ecuaro and seems to rely more on the Spanish names. The recovery of plant use by part of the community has led people to see the value not only of the plants and how they can be used, but also of related customs and traditions, including songs such as the pirecuas and abajeños.

\subsection{Seasonality of plants}

The ecuaro does not look the same throughout the year. It changes in accordance with the seasons of the year. For example, Doña Mónica told me in her interview the following:

I do not buy any of the things that I have here, because everything that I sell is of the season. For example, in these past few days I finished cutting the capulines and now they are gone. The rain helped me almost finish them, do you see, because it rained and was very windy, and they all fell off the trees, and I took those capulines that I could pick and sold them. Then, the native avocados ripened and I picked them too and I sold some by the box; I let others ripen more and sold them little by little, the same with the guindas; there are no guindas left now either, they were really nice, with a brownish color. The pears are also coming along fine. Then I went to see the milpa and the different colored corn.

For this reason, the ecuaro can be changed easily and plants can be added or replanted. All these changes in plant use have an unintentional twin function. On the one hand, they favor the environment, while, on the other, they support the community's own subsistence needs by contributing to a diet that has a variety of foods. However, the removal of areas that could be used for growing plants is what is tending to happen now, without the women being aware of it. 


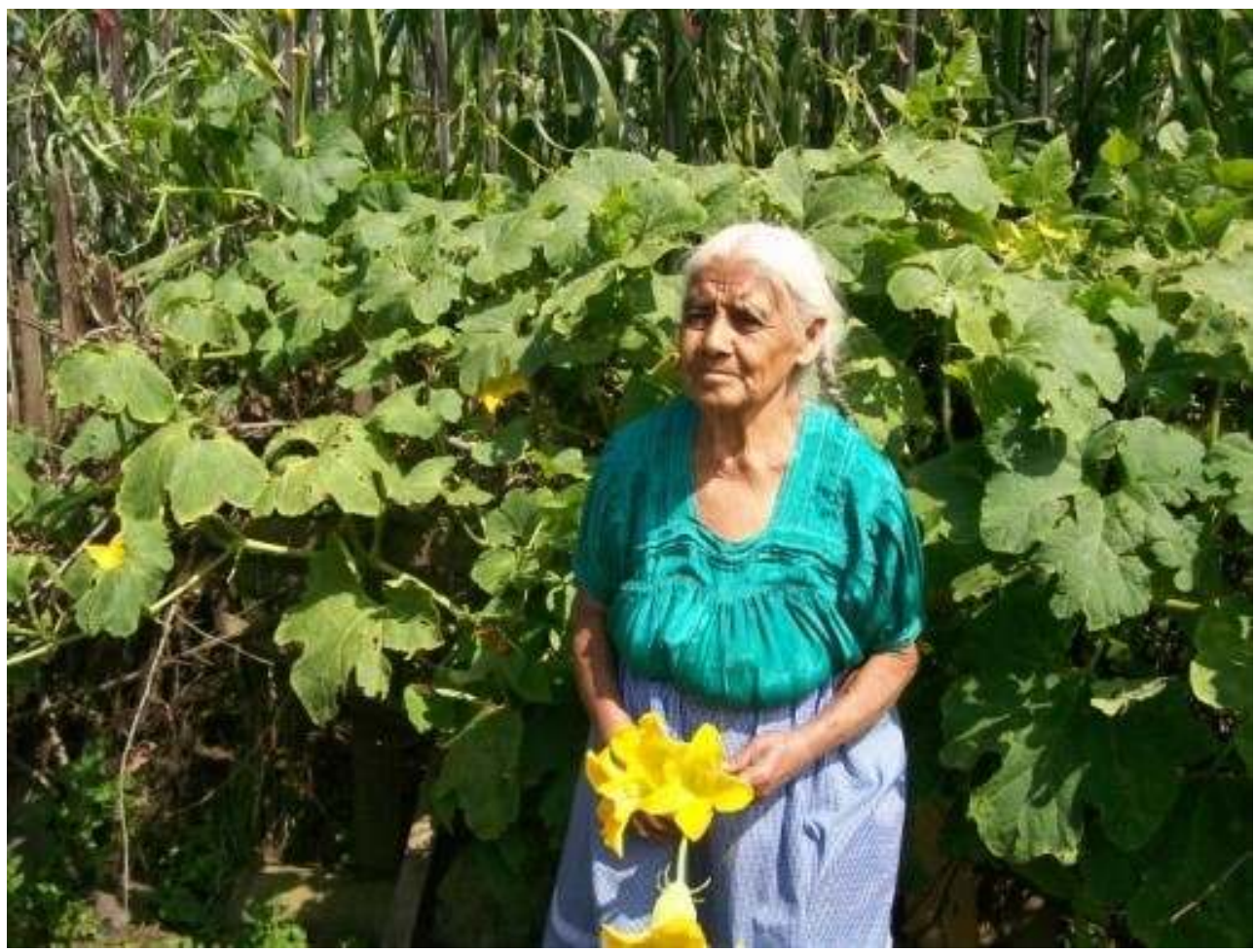

Figure 4: Doña Amanda in her ecuaro with flor de Calabaza (Source: author)

Some of the older women continue to use many plants that they grow in their ecuaro in preparing dishes, but the majority of the women I interviewed only use a small number of ingredients from their ecuaros. Some of the plants are not perennial but only seasonal and need certain environmental conditions to grow and then be replaced by others. For example, if cilantro plants are used up, they can be replaced by another cilantro or by another plant that is needed more in the kitchen or for a special occasion. All the women have chile perón (a yellow chile) in their ecuaros. Even those who do not have ecuaros grow chiles since this ingredient is used all year round, but they also grow other plants, and the ecuaro itself is used in order to grow plants they need due to their economic constraints.

The different varieties of ingredients grown in ecuaros are associated with the seasons but also with religious factors. For example, at the end of the dry season and during Lent and Easter time, nopales are available and red meat cannot be eaten. This product is prepared in different ways in a variety of dishes that most of the people eat. Beginning in the rainy season, there are elotes, fresh corn for uchepos and mushrooms which come from the milpa and forests. Corn is associated with two harvest seasons, and in each, different dishes are prepared, depending on their maturation process. For example, it is only in December that black atole is prepared because it is at that time of the year that the corn stalk (what local people call caña) is dry and ready to be ground. Some women who also grow corn in their ecuaros cut it in time to dry it and use it at this time of the year. If they need tomatoes, they also grow them in their ecuaros as well as a type of quelite called chacuacolis which has also been domesticated and produced for the purpose of preparing dishes. 


\section{Ecuaros are social spaces, embedded in social relations}

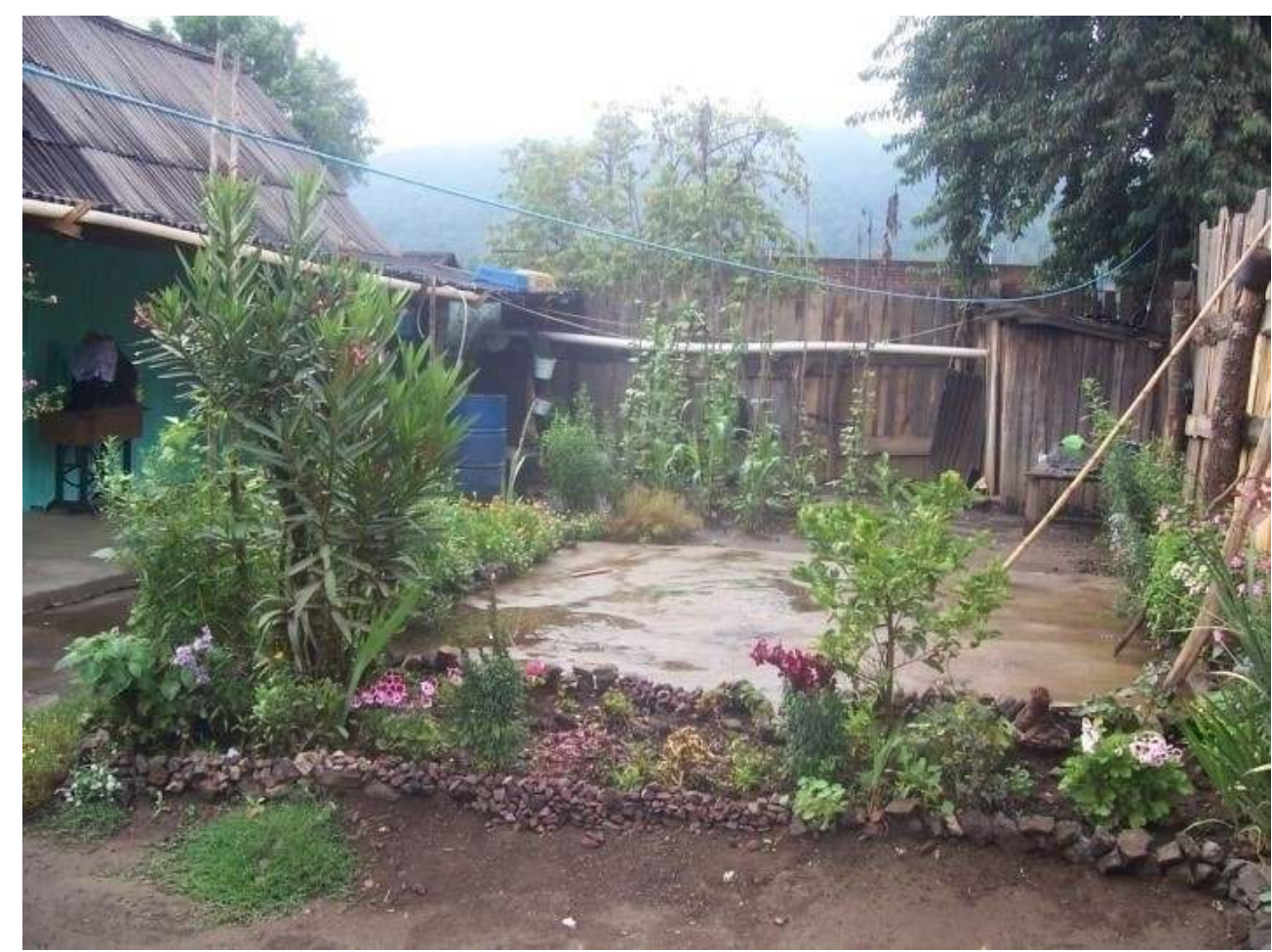

Figure 5: The little that remains of the ecuaro of Doña Estela (Source: author)

While ecuaros were relatively small areas for growing subsistence crops due to the lack of economic resources and the absence of communication infrastructure with the outside world, the few ecuaros that remain continue to serve women and create relationships between them. Some women still exchange products from their ecuaros with each other. However, the ecuaros have become smaller in size and scarce. Most of them are now converted into simple gardens, as spaces for family fiestas and gatherings. They have declined in terms of the area under cultivation. They have instead been incorporated into the home. Tables are set out there for parties, celebrations and gatherings where different dishes are offered.

\subsection{Organization of Work}

41 The work that is involved in maintaining the ecuaro is not as heavy as the work in the milpa. Some women told me that they only sweep and clean their ecuaro every three days (due to the small size of the area cultivated). Only Mónica said that she cleaned her ecuaro every day and to do this she gets up early in the morning and sweeps it and picks up the leaves since she mostly has trees. Beatriz Alicia, who also has an ecuaro, does not clean it every day.

42 Knowledge is passed on from mothers to daughters. It is shared among female relatives in a family when they moved from the hills to live in the community. In the case of Doña Elia, her mother taught her how to keep her ecuaro. It appears that Beatriz Alicia and her 
sister Mónica are the last women with knowledge about ecuaros, but they also have to go to their very elderly mother to ask for her knowledge. Beatriz Alicia is also a single, mature woman, while the daughters of Mónica do not live with her. They have moved to Uruapan. In the case of Doña Elia, she has one daughter who lives in the community, but the main road runs up against her plot of land and leaves no space for an ecuaro. The mothers of Natalia and Coquis do have ecuaros and they are young. It seems that Natalia will pass on knowledge to her daughter Rosaurita, who has inherited land from her mother. Again we find that urbanization and proximity to markets creates a problem for passing on traditional knowledge since interest in maintaining the ecuaro has declined.

\subsection{Distribution and exchange of products}

43 The distribution of ingredients produced in the ecuaros is done in a private way in which money is not essential. Products are distributed among the members of the extended family in occasional exchanges rather than by obligation and this practice reinforces social ties. For example, on some days Coquis took her mother some chacuacolis (a type of quelite) and she gave them to Doña Elia for her to cook them. She also took her a type of bean (Hatza Itzcheri) that only grows in ecuaros in the rainy season (June-August). This bean is used for making corundas called aguacatas. The sowing of different plants has facilitated the exchange of ingredients and communication between women and the creation of social relationships. When Doña Elia received a product from Coquis or Natalia, she did not immediately return the favor. She planned what she would send back, something that the mother of Coquis did not already have, such as Charales, which is a small fish that can be bought in the markets of Uruapan or Paracho and which is seen as a special or luxury food because it is not a local product. Giving charales is a very fine way of expressing gratitude. Doña Elia would also send her fruits or return the favor with atole or just some other dish that she wanted to share with Coquis's mother.

However, there is some sale of ingredients where money is used, for example, in the market. Of the women interviewed, only Mónica said that she goes to the market to sell part of what she produces in her ecuaro. The milpa provides several other items for sale in the market. Every Friday is dedicated exclusively to making tortillas, tamales and gorditas which are later sold and the income is used to buy the weekly needs at the market in Uruapan. They probably invest a remainder of this income in fiestas or in what Doña Elia considers necessary, since she is in charge of the well-being of her children and extended family that lives with her.

In reality, little money is spent on processed foods because they rely on naturally produced foods, but not always. Relatives help each other to meet their subsistence needs. The different dishes are also prepared with other ingredients, but not all of these come from the ecuaro. There is a combination of factors that I mentioned above that explain the decline in production of the few ecuaros that still remain. The final products are the dishes that are elaborated with certain ingredients that come from the ecuaros, as well as the social relations between women. As ecuaros decline, these relationships are becoming endangered. At the same time, a source of extra income for women is being lost. 


\subsection{Links with family, kin, social relations} independence from the big markets established in urban areas. They were autonomous as a community and the capacity to be autonomous is still latent, although more and more this self-sufficiency is being restricted because now they themselves depend for their food on small stores in the community and markets in other towns. The population of the community was also much lower than today. As a result, the women are not completely autonomous in the way that they once were able to meet their food needs, but they do have the capacity to regain a greater degree of autonomy. The community still retains the social relationships created through their customs, in addition to the religious aspect such as the processions held each Saturday (Illsley et al. 1988). restricted to what was most abundant in each season. Today new desires are created in the community since people have greater mobility to go to markets and buy goods that they feel like cooking. For example, Atole de Grano was prepared with ingredients bought in the market because in the milpa the corn was not yet ripe enough to prepare this type 
of atole. They also have to take into account the large number of people who they have to feed at the church.

Returning to women's autonomy, I think that women were more autonomous before with regard to production because they grew their own foods and contributed in a more active way to their independence, while also conserving biodiversity.

With regard to family ties, they still exist and relatives still collaborate with each other by exchanging products that they grow, but this activity is more and more sporadic. There were not many times when the mother of Coquis took products from her ecuaro to her mother-in-law, Doña Elia. However, these ties are more evident in the fiestas, since all the relatives and close friends attend the fiestas and support each other with whatever they can. It is at the fiestas that I saw how relatives exchanged a good amount of different products that they brought from their ecuaros.

\section{Ecuaros and outside linkages with the market}

\subsection{Gender and independence of income}

Products from ecuaros are sometimes sold. Mónica, the sister of Beatriz Alicia, told me that she in fact lives from what she produces in her ecuaro. She has economic independence since she does not depend on her husband's income to live, although being economically independent is not seen as a priority for women in the community. Mónica mentioned that her husband does not know how to work. When I asked her what he does for a living, she said construction. The important point here is that while those who come from the outside would consider that their husbands do work, according to community customs, if husbands do not work in the fields then "they do not know how to work". Mónica is also aware that her husband's work is no longer in the fields as was the custom.

\subsection{Selling products in the market}

Many of the products that women grow in their ecuaros and milpa are sold in places outside the markets, on street corners or nearby, since the more established stalls belong to those with more money to invest and not to indigenous women who come from their communities to sell the small amounts that they produce. Some women also sell what they collect in the forest. I saw this in December when I found several women selling Flor de Pena and Heno to adorn traditional Nativity cribs. Other women resell what they buy at orchards that produce a great deal of fruit. For example, Doña Benemérita would go to cut peaches at an orchard that did not belong to her and then resold them at the market in Paracho. This activity left her with a little profit. In the case of Doña Elia, who did not have an ecuaro, her husband does have a milpa and the corn is used for making different products, for example, tamales, tortillas and gorditas that each Saturday she goes to sell at "La Ranita" market. The sister of Beatriz Alicia sells her own products at the market in Uruapan. Each of these activities provides an extra income to these women and this gives them a degree of economic independence with regard to their husbands, the state and the market. 


\subsection{Decline of ecuaros} suffers, such as the lack of water, high birth rates and external pressures such as unregulated forest exploitation, in addition to a lack of information and awareness in the community. As mentioned throughout this paper, there are several factors that together contribute to the lack of attention, but the most serious one is the way that women are devalued, since the workload of women in the community is very heavy and equal to that performed by men, but with the difference that women also have other responsibilities among which are the raising of children and looking after the family economy.

\section{Conclusions}

This study has attempted to show the importance of ecuaros and the role played by women in local food systems and social ties, while recognizing challenges to their future viability. The study is not intended to be conclusive and further research is necessary to determine the extent to which the time and energy invested in ecuaros helps households meet their food needs.

By placing the micro-level processes of ecuaro production in the context of the macrolevel transformation of agriculture, we can appreciate both the value and vulnerability of home gardens. At the macro-level we see the tendency for Mexico and other countries to lose their food sovereignty because of the promotion of export-oriented crops and the increasing reliance on food imports. It is this tendency that is also occurring at the local level, where the communities are also becoming more and more dependent on urban or local markets rather than their own subsistence production. This paper has shown how the ecuaros have in the past allowed Purhépecha people to meet their food needs, but also how this system has gone into decline as a result of a variety of factors. As the ecuaro declines, the social relationships between women are also transformed as the individual exchanges that occur in the ecuaro are being undermined, although some women still engage in this practice which reinforces social ties. A tendency at another level is the emergence of a different kind of exchange which occurs in social events such as family gatherings and fiestas where men are named godfathers based on their financial stability. The godfathers have enough money to buy expensive fruits and traditional clothes which they then distribute as gifts.

The capacity (knowledge and resources) to regain a greater degree of autonomy in food self-sufficiency still exists, even if the area available is smaller. Such autonomy will also empower women's position, as they will gain in prestige and benefits from the maintenance of social ties that support them and their work. This also benefits the community by strengthening self-sufficiency and more harmonious social relations.

Ecuaros are important for the diversity of ingredients that they produce. This diversity is reflected in a wide variety of dishes that are prepared in the community and a healthy diet of nutritious foods. Ecuaros also reveal the importance of cultural diversity that benefits humanity as a whole. The fact that most of the women do not use fertilizers in their ecuaros but rather pine soil makes this kind of subsistence system an organic one. Keeping diversity alive in a small area of production makes the ecuaros potentially important. Unfortunately, the tendency of current public policies does not encourage this 
kind of production. Instead, we have seen a gradual decline in the production of ecuaros and now the government is undermining food sovereignty and the milpa as the main system of local food production.

In response to the failure of neoliberal policies and free trade agreements to reduce hunger, rural social movements have emerged in many countries, including Mexico, to demand that food be considered a right rather than just another commodity. Many of these movements participate in transnational networks such as Vía Campesina and have worked together to contest the dominant model of food production as well as promote sustainable, agro-ecological alternatives (Martinez \& Rosset 2010). As McMichael has argued:

...states as well as communities, especially of producers, should have the right to develop their own policy instruments, including protections, so that inhabitants can be provisioned adequately and nutritionally with the food they need, and in culturally and ecologically appropriate ways (2010, p. 67).

While it is important to recognize the political role of Vía Campesina as a transnational social movement, it is also necessary to value women's daily practices at the household level that demonstrate the social, economic and ecological benefits of local food systems such as ecuaros. This study has sought to contribute to our knowledge of both the promise and limitations of home gardens for confronting the ongoing crisis in agriculture while offering lessons for how to increase food self-sufficiency and promote biodiversity conservation at the same time.

\section{BIBLIOGRAPHY}

Alcalá, J. de. (2010). Relación de Michoacán. Estudio introductorio de Jean-Marie G. Le Clézio.

Zamora, Michoacán: El Colegio de Michoacán.

Barkin, D. (1985). El fin de la autosuficiencia alimentaria. México: Centro de Ecodesarrollo \& Editores Océano.

Bellow, S. \& Baviera, M. (2010). Food Wars. In F. Magdoff \& B. Tokar (Eds.), Agriculture and Food in Crisis: Conflict, Resistance and Renewal, (pp. 33-50). New York: Monthly Review Press.

Christie, M. (2002). Naturaleza y sociedad desde la perspectiva de la cocina tradicional mexicana: género, adaptación y resistencia. Journal of Latin American Geography, 1 (1), 17-42.

Dunmire, W. (2004). Gardens of New Spain: how Mediterranean Plants and Foods Changed America. Austin: University of Texas Press.

Galhena, D. et al. (2013). Home gardens: a promising approach to enhance household food security and wellbeing. Agriculture \& Food Security, 2 (8), 1-13.

Gasco, J. (2008). "Le da alegría tener flores": Homegardens in the Soconusco region of Chiapas, Mexico. Journal of Ethnobiology, 28 (2), 259-277. 
Illsey, C. et al. (1988). Recursos naturales y alimentación en la Sierra Purépecha. In A. Avila et al. (Eds.), ¿Producir para la destrucción?, (pp. 243-66). México: Centro de Ecodesarrollo/Fundacion Friedrich Naumann.

Keleman, A. (2010). Institutional support and in situ conservation in Mexico: biases against smallscale maize farmers in post-NAFTA agricultural policy. Agriculture \& Human Values, 27, 13-28.

Lok, R. (2001). A better understanding of traditional homegardens through the use of locally defined management zones. Indigenous Knowledge \& Development Monitor, 9 (2), 14-19.

Magdoff, F. \& Tokar, B. (2010). Agriculture and Food in Crisis: An Overview. In F. Magdoff \& B. Tokar (Eds.), Agriculture and Food in Crisis: Conflict, Resistance and Renewal, (pp. 9-30). New York: Monthly Review Press.

Maldonado Aranda, S. (2012). Droga, violencia y militarización en el México rural: el caso de Michoacán. Revista Mexicana de Sociología, 74 (1), 5-39.

Mapes, C. (s/f). El papel de la milpa en la cultura y en la subsistencia Purhépecha en el Lago de Pátzcuaro. (Documento inédito de circulación interna). Michoacán, México.

Martínez, M. \& Rosset, P. (2010). La Vía Campesina: the birth and evolution of a transnational social movement. Journal of Peasant Studies, 37 (1), 149-175.

McMichael, P. (2010). The World Food Crisis in Historical Perspective. In F. Magdoff \& B. Tokar (Eds.), Agriculture and Food in Crisis: Conflict, Resistance and Renewal, (pp. 51-67). New York: Monthly Review Press.

Mintz, S. (1996). Tasting Food, Tasting Freedom. Excursions into Eating, Culture and the Past. Boston: Beacon.

Mintz, S. (2006). Food at moderate speeds. In R. Wilk (Ed.), Fast Food/slow Food: the cultural economy of the global food system, (pp. 3-11). Lanham: Altamira Press.

Murrieta, R. \& Winkler-Prins, A. (2003). Flowers of Water: Homegardens and gender roles in a riverine Caboclo community in the Lower Amazon, Brazil. Culture \& Agriculture, 25 (1), 35-47.

Rodríguez Lazcano, C. (1993). El trabajo de la mujer entre los campesinos tarascos. Revista de la Universidad Michoacana, 7, 71-78.

Singh, R. et al. (2013). Elderly Adi Women of Arunachal Pradesh: "Living Encyclopedias" and Cultural Refugia in Biodiversity Conservation of the Eastern Himalaya, India. Environmental Management, 52, 712-735.

The Nature Conservancy. (2007). Biodiversidad en el Centro y Occidente de México. Planeación ecorregional: avances y próximos pasos. México: Parques en Peligro/USAID.

Zaldívar, M., Rochas, O., Castro, E. y Barrantes, R. (2002). Species diversity of edible plants grown in homegardens of Chibchan Amerindians from Costa Rica. Human Ecology, 30 (3), 301-316.

\section{NOTES}

1. This paper was presented at the XXXIV Congress of the Latin American Studies Association (LASA), New York, May 27-30, 2016. 


\section{ABSTRACTS}

This paper focuses on the importance of ecuaros (home gardens) in a Purhépecha community in the western state of Michoacán, Mexico. Despite the loss of tradition in conserving ecuaros, these systems represent a potential economic benefit for community members, as well as contributing to the preservation of biodiversity. The role of ecuaros has been understudied but offers important lessons in the conservation of culturally significant plants and food varieties. The paper presents results of ethnographic research in the Purhépecha community of San Lorenzo to examine the role of ecuaros in food production and community traditions, as well as noting their current decline. It compares the diverse uses of ecuaros with regard to the various aesthetic, economic and seasonal aspects of ecuaro production. The paper considers ecuaros as social spaces through which knowledge is passed on from mothers to daughters and notes how the exchange of ecuaro products occurs, for example, in providing gifts that help strengthen family and community ties. The paper also discusses the relationships between ecuaros and outside markets, particularly the impacts of such relationships on women's incomes and the decline of ecuaros. The paper concludes by reflecting on the challenges facing ecuaros and the need for new policies to recognize and support this important alternative in the face of declining food sovereignty and the loss of biodiversity.

Este ensayo examina la importancia de los ecuaros (jardines caseros) en una comunidad Purhépecha en el estado occidental de Michoacán, México. A pesar de la pérdida de la tradición de conservar los ecuaros, estos sistemas representan un potencial beneficio económico para los miembros de la comunidad, además de contribuir a la preservación de la biodiversidad. El papel del ecuaro no ha recibido suficiente atención por parte de los investigadores, pero nos proporciona lecciones importantes para la conservación de variedades de plantas y alimentos culturalmente significativos. Este ensayo presenta los resultados de trabajo etnográfico realizado en la comunidad de San Lorenzo para examinar el papel de los ecuaros en la producción de alimentos y en la conservación de tradiciones comunitarias, además de notar su declinación en la actualidad. Compara la diversidad de usos a que se dedican los ecuaros con respecto a los aspectos estéticos, económicos y temporales de la producción de los ecuaros. El ensayo considera a los ecuaros como espacios sociales en los cuales los saberes se transmiten de madres a hijas y da atención a la manera en que este intercambio de los productos del ecuaro se realiza, por ejemplo, como regalos ayuda a fortalecer los lazos familiares y comunitarios. También examina la relación entre los ecuaros y los mercados externos, sobre todo el impacto de éstos en el ingreso de las mujeres y en el decaimiento de los ecuaros. Concluye con algunas reflexiones sobre los retos que enfrentan los ecuaros y la necesidad de promover nuevas políticas que reconozcan y apoyen a esta importante alternativa frente a la disminución de la soberanía alimentaria y la pérdida de la biodiversidad.

\section{INDEX}

Keywords: Biodiversity, conservation, home gardens, women, Purhépecha

Palabras claves: Biodiversidad, conservación, ecuaros, mujeres, Purhépecha 


\section{AUTHOR}

WENDY M. HARVEY

New Mexico State University, Estados Unidos

maharvey@nmsu.edu 